\title{
FAMILIAL CEREBRAL CAVERNOUS MALFORMATIONS
}

\section{Rio de Janeiro study and review of the recommendations for management}

\author{
Flávio Domingues', Emerson L. Gasparetto², Ricardo Andrade, Fabio Noro³, Antônio Eiras³, \\ Judith Gault ${ }^{4}$, Carlos Eduardo Silva Correia ${ }^{5}$, Jorge Marcondes de Souza
}

\begin{abstract}
Objective: Multiple cerebral cavernous malformation (CCM) is the hallmark of familial presentation of cavernous malformation in the brain. We describe an ongoing Familial Cerebral Cavernous Malformation Project in the Rio de Janeiro state showing genetic profile and the pattern of emergent neuroimaging findings of this particular population besides a review of the updated recommendations for management of familial CCM versus patients harboring sporadic lesions. Method: Four families of our cohort of 9 families were genetically mapped showing mutational profile linked to CCM1. The neuroimaging paradigm was shifted from T2* gradientecho (GRE) sequence to susceptibility weighting MR phase imaging (SWI). Results: Only two index cases were subjected to surgery. There was no surgical intervention in any of the kindreds of our entire cohort of 9 families of our Neurovascular Program within seven years of follow-up. The genetic sequencing for mutacional profile in four of these families has demonstrated only CCM1 gene affected. Our management of the familial CCM is according to the review of the literature recommendations. Conclusions: The Project of Familial Cerebral Cavernous Malformations of Rio de Janeiro detected mutations of the gene CCM1 in the first four families studied. Familial cavernous malformation are to be settled apart from the more common sporadic lesion. A set of recommendations was searched for in the literature in order to deal with these specific patients and kindreds.
\end{abstract}

KEY WORDS: genetics, mutation, vascular malformation, cavernous malformation, cavernoma.

\section{Malformação cavernosa cerebral familiar: um estudo no Rio de Janeiro e revisão das recomendações para tratamento}

Resumo - Objetivos: A apresentação de malformação cavernosa cerebral (CCM) através de múltiplas lesões cerebrais é a marca da forma familiar da doença. Os autores descrevem o Projeto Malformação Cavernosa Cerebral Familiar, em andamento no Rio de Janeiro, demonstrando o perfil genético e o padrão atual de achados neurorradiológicos dessa população específica e uma revisão das recomendações atuais para o manuseio e tratamento dos portadores dessa forma da doença versus os pacientes com malformação cavernosa cerebral esporádica. Método: Quatro familias de nossa coorte de 9 familias foram completamente mapeadas geneticamente e demonstraram padrão mutacional sempre ligado ao gene CCM1. O paradigma de neurimagens dessa população foi mudado para a seqüência de susceptibility weighting MR phase imaging (SWI) em substituição à seqüência T2* gradient-echo (GRE). Resultados: Apenas 2 casos indices foram submetidos à ressecção cirúrgica. Não houve intervenção cirúrgica em nenhum outro parente de toda a coorte de 9 familias no período de sete anos de acompanhamento. O sequenciamento genético em busca do perfil mutacional foi completado em 4 familias demonstrando o acometimento do gene CCM1 em todas. O manuseio e tratamento de nossa população de malformação cavernosa cerebral familiar está de acordo com a revisão feita sobre recomendações da literatura. Conclusão: O Projeto Malformação Cavernosa Cerebral Familiar detectou mutações do gene CCM1 nas primeiras quatro famílias estudadas. Os portadores dessa forma de malformação cavernosa cerebral da doença devem ser considerados à parte na rotina de avaliação e tratamento em relação à forma esporádica da doença. As recomendações foram buscadas na literature para nortear o manuseio dessa população específica.

PALAVRAS-CHAVE: malformação cavernosa, cavernoma, genética, mutações, malformação vascular cerebral.

\footnotetext{
The Familial CCM Research Study Group of the Universidade Federal do Rio de Janeiro (UERJ), Rio de Janeiro RJ, Brazil: 'Service of Neurosurgery of the Hospital Universitário Clementino Fraga Filho; ${ }^{2}$ Department of Radiology of the Hospital Universitário Clementino Fraga Filho and CDPI; ${ }^{3}$ Department of Neuroimaging of the Hospital Barra D'Or, Rio de Janeiro RJ, Brazil; ${ }^{4}$ Department of Neurosurgery and Psychiatry, University of Colorado at Denver and Health Sciences Center, Denver (USA); ${ }^{5}$ Medical Student (PINC), Faculdade de Medicina, UFRJ.

Received 17 July 2008, received in final form 17 September 2008. Accepted 7 October 2008.

Dr. Jorge Marcondes de Souza - Serviço de Neurocirurgia do Hospital Universitário Clementino Fraga Filho - Rua Rodolpho Rocco 255 - $21941-913$ Rio de Janeiro RJ - Brasil.E-mail:jmarcondes@hucff.ufrj.br
} 
Cerebral cavernous malformations (CCM) are vascular lesions formed by histologically enlarged capillary cavities without intermixed brain parenchyma. CCM are included amongst the most frequent vascular malformation of the central nervous system (CNS), with prevalence of $0.1-0.5 \%$ in the general population. However, there is a large storage of the non-diagnosed carriers of the pathology in the population ${ }^{1,2}$. Patients with CCM may experience an average rate of bleeding of 0.7 to $1.1 \%$ per lesion per year, ${ }^{3,4}$. The coexistence of CCM and development venous anomaly (DVA) is the most common intracranial mixed vascular malformation ${ }^{5}$, with the association ranging between $24 \%^{6}$ and $100 \%$ raising a possible causal relationship linking these two entities ${ }^{8}$. Patients harboring CCM usually presented around third through fifth decades of life with seizures, cerebral hemorrhage, focal neurological deficits or headaches. Hemorrhages in cavernous malformation are characterize by computerized tomography (CT) as lesions with high density (acute bleeding) or by magnetic resonance imaging (MRI) as images suggesting intra and/or perilesional recent bleeding associated to recent symptoms or neurological deficits. Seizures are, by far, the most frequent presentation followed by other signs and symptoms related to hemorrhage. Sporadic and familial forms of the disease have been described and the pattern of inheritance in families is mendelian autossomal dominant with high penetrance. Usually the sporadic CCM phenotype is the one of a single lesion whereas multiple lesions are usually characteristic of probands of families ${ }^{9-12}$. Three genes have been already identified: CCM1 gene or KRIT1, CCM2 gene or MGC4607 and the CCM3 gene or PDCD10. The CCM1 gene was mapped to the 7q11.2-21 region, while CCM2 and CCM3 to 7p13-15 and $3 q 25.2-27$, respectively. The most frequent and well studied is the CCM1 gene with mutational analyses showing a Hispanic-American ancestral haplotype ${ }^{13,14}$.

There is also a recent awareness regarding a benign clinical behaviour of the disease among patients harboring CCM1 genotype compared to the sporadic ones'. The discovery of a spinal cord CCM should raise the suspicion of the familial form of the disease ${ }^{15}$ and pregnancy is linked to the hemorrhagic risk but there are no solid evidences to make firm recommendations. MRI is the most sensitive test for CCM detection. The T2* gradient-echo (GRE) sequence has been considered the best one to detect the presence of the lesion hemossiderin deposit and is specially important in uncovering multiple CCMs, the phenotype of the familial form. Recently a new MRI sequence the susceptibility weighting MR phase imaging (SWI), has been described and may have superior accuracy in detecting multiple CCMs and the associated DVAs ${ }^{16}$.

The detection of additional lesions in an apparently sporadic CCM is the key point for the familial diagnostic workup with the strong recommendation for the use of one of the mentioned sequences due to their higher sensitivity to hemoglobin degradation products. The dynamic state of the disease is demonstrated by up to $30 \%$ of de novo lesions reported during follow-up ${ }^{17,18}$. Manifestations outside CNS are unusual with retinal and cutaneous lesions being the most commonly reported ${ }^{19,20}$. Kindreds known as carriers of a CCM mutation may not have any lesion in T2*GRE with radiologically undetected or incomplete penetrance disclosing the importance of molecular testing in the suspicion of familial disease ${ }^{21}$. We have began the screening of familial CCMs at the city of Rio de Janeiro by the year 2000, after the approval of the Project of Familial Cerebral Cavernous Malformations of Rio de Janeiro, by the Ethics Committee for Human Research of the Hospital Universitário Clementino Fraga Filho.

We present a summary of clinical, genetic and imaging findings in the first four families as well as the current recommendations for the diagnosis and management of familial CCMs.

\section{METHOD}

Four families of our cohort of CCM families have their mutational profile completed and were allocated to this study since the year 2001.

Since 2006 we have added to our MRI protocol of investigation the SWI sequence, as we have recently demonstrated its higher sensibility to detect hemossiderin deposits compared to T2weighted fast spin echo and T2* GRE sequences ${ }^{16}$. This sequence will incorporate new data that may contribute to better knowledge regarding natural history of CCM in the familial setting.

Two sporadic cases also studied at our program have multiple lesions on $\mathrm{T} 2{ }^{*}$-weighted GRE sequence and are probably probands of familial CCM with kindreds not yet with neuroimaging representation.

We have just detected another familial case from re-imaging with GRE and SWI sequences a patient operated upon for an isolated lesion before the systematic use of T2*GRE sequence. SWI and GRE sequences depicted multiple lesions and two affected brothers (Figure).

\section{Germline mutation analysis}

Genomic DNA was isolated from blood using standard salting out procedures. PCR products were generated across each CCM1, coding exons using standard conditions with 0.03 units $/ \mu \mathrm{L}$ AmpliTaq $^{\circledR}$ Gold (Applied Biosystems, Foser City, CA, USA) and 0.003 units/ $\mu \mathrm{L}$ Pfu DNA polymerases (Stratagene, La Jolla, CA, USA). Mutations were detected with the Transgenomic WAVE ${ }^{\circledR}$ System (Transgenomic, Omaha, NE) that utilizes denaturing High Pressure Liquid Chromatography (dHPLC). Conditions were optimized using sequence analysis (WAVEMAKER ${ }^{\text {TM }}$ software) and by trials at various dHPLC elution temperatures. 

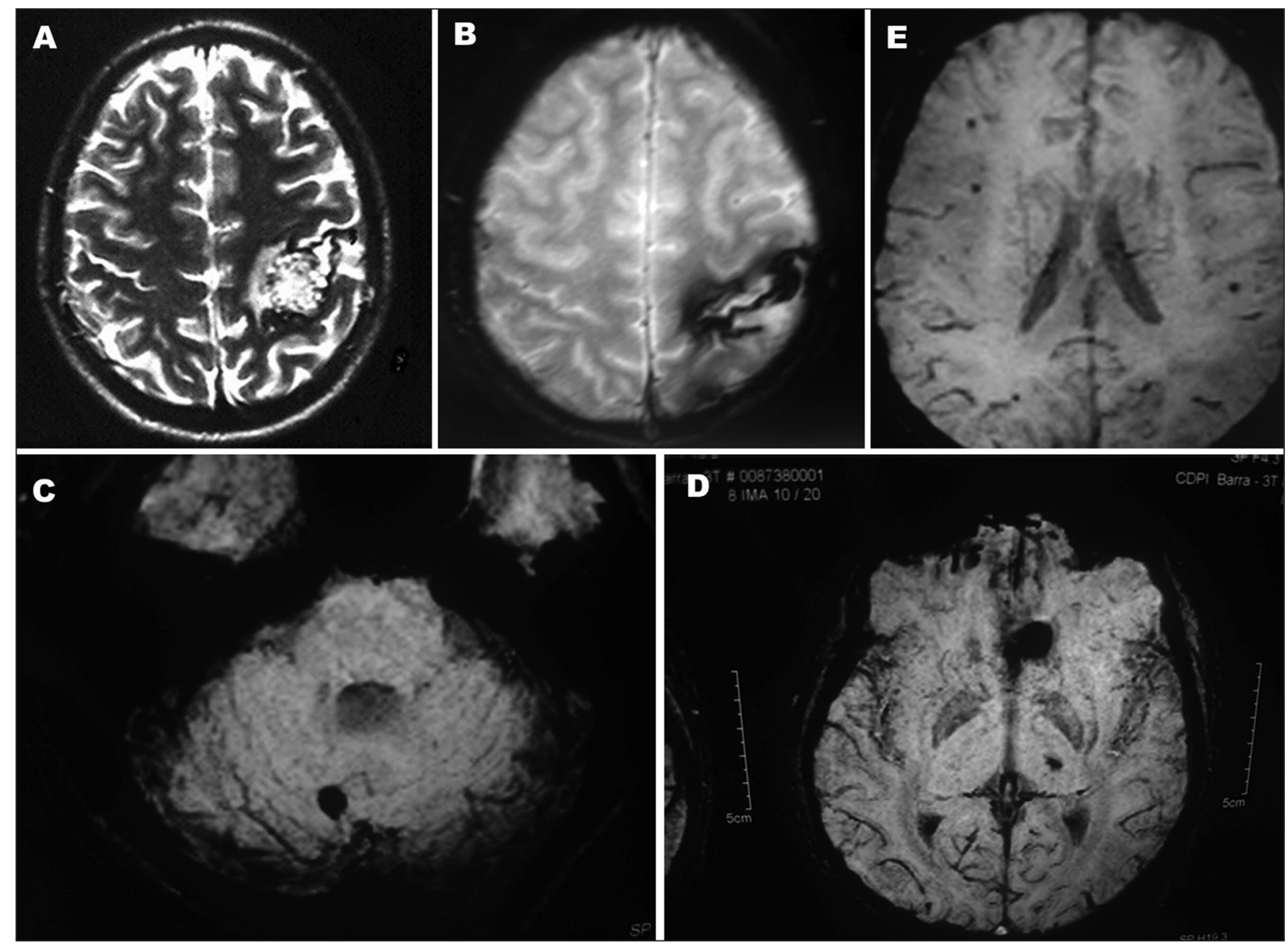

Figure. (A) MRI T2-weighted imaging depicting a subcortical CCM in the left central area before GRE and SWI. (B). A recent T2*-weighted GRE sequence of the same area after resection of the lesion. (C) SWI sequence and additional CCM and associated DVA in the cerebellum. (D) SWI sequence and basal frontal and thalamic lesions. (E) SWI showing multiple lesions in a asymptomatic younger brother.

Four germline mutation were identified, all of them in the CCM1 gene in the exons 9, 1016 and 19. The mutation on the exon 10 is a novel one, not yet identified in the literature.

A literature review was done regarding management of familial CCM mainly throughout the Medline database (PUBmed) from 1997 to February 2008 in order to confront with our population management protocol.

\section{RESULTS}

Four families with more than one member featuring the phenotype of multiple CCM lesions were allocated to our cohort and genetically mapped accordingly. We have also two sporadic CCM patient with multiple lesions on MRI and no mutacional profile yet analized.

The genetic sequencing for mutacional profile in these four families in Rio de Janeiro has demonstrated only the CCM1 gene affected (Table). Most lesions are in the supratentorial location, with cortical-subcortical distribution. All the families have at least one kindred with multiple le- sions at the brainstem and all of them asymptomatic depicting a different clinical behavior from sporadic ones whereas this location is a predictor for recurrent bleeding.

Only two patients, both of them index cases, were submitted to surgical removal. One patient was a 18yrs-old male, with multiple bleeding episodes and clear growing of a right caudate CCM lesion that was ressected throghout frontal transcortical route. His 73-years-old father and a 40-years-old brother harbored multiple lesions and both of them were asymptomatic. All the other several lesions seen in this patient had never raised any manifestations in seven years of follow-up. The second one was a 40-yrs-old female, with progressive paraparesis up to the point of being wheelchair bounded. The thoracic spinal cord MRI of the thoracic spinal cord depicted a typical CCM lesion leading to the intervention. There was no surgical intervention in any of the kindreds of our entire cohort of 9 families of our Neurovascular Program within seven years of follow-up. 
Table. Germline KRIT7 mutations.

\begin{tabular}{cccc}
\hline Exon & Family & Mutation (nucleotide*) & Predicted effect (amino acid) \\
\hline 9 & F 1 & C712T & L238F/splicing \\
10 & F 2 & + A@796 & fs@266/X267 \\
16 & F 3 & +T@1688 & fs@563/X567 \\
19 & F 4 & G2064A & W688X \\
\hline
\end{tabular}

*Nucleotide position relative to ATG cDNA start; fs, frame shift.

\section{DISCUSSION}

Our results of the familial CCM mapping are in accordance to the literature with clinical and neuroimaging findings depicting a favorable outcome in families harboring the CCM1 mutacional profile'. Some recommendations in the reviewed literature are the same for the sporadic lesion but a few differences should be highlighted.

Anticoagulants, even prophylactic, or platelets inhibitors should be avoided due to the higher risk for bleeding in CCM patients ${ }^{21}$. Cocaine and other illegal stimulating drugs may cause intracranial hemorrhage and should be also abandoned.

Surgical removal is indicated in familial CCM when detecting pharmaco-resistent seizures, symptomatic rebleeding or progressive focal neurological deficit due to mass effect. The prognosis of familial CCM is not well known ${ }^{9}$ and most studies have shown an indolent course even with the evidences that $30 \%$ of the carriers will show new lesions ${ }^{18}$.

As the MR sequences are progressing to increase sensitiveness regarding lesion detection ${ }^{16}$ the question that arises is what is the significance of solitary or sporadic CCM and how many of them would end up as a hidden familial disease. Concomitant progress in molecular detection of new mutants or a new gene (the CCM 4) and/ or higher neuroradiological detection capability will uncover the real incidence of the sporadic cavernous malformation.

The identification of the three CCM genes uncover the future chances for molecular screening and individual clinical management. Even sporadic cases with multiple lesions can be considered genetically affected ${ }^{14}$. Unaffected individuals pertaining to a well known CCM family are the most challenging due to the uncertainty of imaging mapping. Relatives without CCM lesion, specially the young ones, may develop it later and even molecular screening is left with around $10 \%$ of uncertainty as there is a probability of finding the CCM 4 gene ${ }^{14}$.

There is no clear consensus on recommendation for neuroimaging and/or molecular study of the asymptom- atic relative of a CCM patient, even in the setting of $\mathrm{fa}$ milial disease, regarding clinical management.

In conclusion, the ongoing Project of Familial Cerebral Cavernous Malformations of Rio de Janeiro detected mutations of the gene CCM1 in the first four families studied. Familial cavernous malformation are to be settled apart from the more common sporadic lesion that usually come to the neurologist attention. With the fast advance of of genetic background and neuroimaging for maping those families a set of recommendations was searched for in the literature in order to deal with these specific patients and kindreds.

\section{RECOMMENDATIONS}

1. In any case of suspected CCM a MRI with T2*weighted GRE or, even better, SWI sequence should be performed in order to exclude and/or better mapping multifocal lesions.

2. Whenever in doubt facing a new lesion with surrounding edema, rapid recurrent hemorrhage or growing in size, there is no recommendation for stereotaxic biopsy. Microsurgical removal, with imaging-guided neuronavigation if necessary, is recommended.

3. There is a recommendation to avoid anticoagulants, even prophylactic or platelets inhibitors due to the higher risk for bleeding. Cocaine and other illegal stimulating drugs may cause intracranial hemorrhage and should be abandoned too.

4. Multiple lesions and pharmaco-resistent epilepsy may be challenging since the prognosis for seizure control depends upon very careful and accurate mapping of the epileptogenic lesion. Refractory seizures with temporal lobe lesion responsible for the clinical picture should be submitted to lesionectomy and, if possible, resection of the nearby gliotic tissue. If MRI shows additional ipsilateral hipoccampus atrophy and/or high signal on FLAIR sequence concomitant amygdalo-hipoccampectomy may be considered.

5. Familial CCM, on the contrary of the sporadic ones, tend to have indolent brainstem lesions in our experience and should be managed conservatively unless 
clearly growing in size or with bleeding approaching the surface.

6. Family members should be followed expectantly. Surgery is considered only in cases with obvious growing lesions with mass effect or lesion with well documented recurrent bleeding.

\section{REFERENCES}

1. Rigamonti D, Drayer PB, Johnson PC, Hadley MN, Zabramski J, Spetzler RF. The MRI appearance of cavernous malformations (angiomas). J Neurosurg 1987;67:518-524.

2. Otten P, Pizzolato GP, Rilliet B, Berney . A propos de 131 cas d'angiomes caverneux (cavernomes) du SNC, repérés par l'ánalise rétrospective de 24.535 autopsies. Neurochirurgie 1989;35:82-83.

3. Robinson JR, Awad IA, Little JR. Natural history of the cavernous angioma. J Neurosurgery 1991;75:709-714.

4. Moriarity JL, Wetzel M, Clatterbuck RE et al. The natural history of cavernous malformations: A prospective study of 68 patients. Neurosurgery1999;44:1166-1176

5. Abe T, Singer RJ, Marks MP, Norbash AM, Crowley RS, Steinberg GK. Coexistence of occult vascular malformation and development venous anomalies in the central nervous system: MRI evaluation. AJNR Am J Neuroradiol 1998;19:51-57.

6. Abdulrauf SI, Kaynar MY, Awad IA. A comparison of the clinical profile of cavernous malformations with and without associated venous malformations. Neurosurgery 1999;44: 41-47.

7. Porter RW, Detwiler PW, Spetzler RF, Lawton MT, Baskin, Derksen PT. Cavernous malformations of the brainstem: experience with $100 \mathrm{pa}-$ tients. J Neurosurgery 1999;90:50-58.

8. Pozzati E, Acciari N, Tognetti F, Marliani F, Giangaspero F. Growth, subsequent bleeding and de novo appearance of cerebral cavernous angioma. Neurosurgery 1996;38:662-670.

9. Gault J, Sain S, Hu L-J, Awad IA. Spectrum of genotype and clinical manifestations in cerebral cavernous malformations. Neurosurgery 2006;59:1278-1285.
10. Labauge P, Laberge S,Brunereau L.Cerebral Cavernous angiomas: clinical and genetic features in 57 french families. Lancet 1998;352:1892-1897.

11. ZabramskiJM, Wascher TM, Spetzler RF. The natural history of familial cavernous malformations. Results of an ongoing study. J Neurosurg 1994;80:422-432.

12. Brunereau L, Labauge $P$, Tornier-Lasserve et al. Familial form of intracranial cavernous angioma. MR imaging findings in 51 families. Radiology 2000;214:209-216.

13. Gunel M, Awad IA, Finberg K et al.A founder mutation as a cause of cerebral cavernous malformation in Hispanic Americans. N Engl J Med 1996;334:946-951.

14. Labauge P, Denier C, Bergametti F, Tournier-Lasserve E. Genetics of cavernous angioma. Lancet Neurol 2007;6:237-44.

15. Vishteh AG, Zabramski JM, Spetzler RF. Patients with spinal cord cavernous malformations are at an increased risk for multiple neuraxis cavernous malformations. Neurosurgery 1999;45:30-33.

16. Souza J, Domingues RC, Cruz Jr LCH, Domingues FS, Iasbeck T, Gasparetto E.L. Susceptibility-weighted imaging for the evaluation of patients with familial cerebral cavernous malformations: a comparison with T2-weighted fast spin-echo and gradient-echo sequences. Am J Neuroradiol AJNR 2008;29:154-158.

17. Brunereau L, Levy C, Laberge S, Houteville J-P, Labauge P. De novo lesions in familial form of cerebral cavernous malformations: clinical and MR features in 29 Non-hispanic families. Surg Neurol 2000;53:475-483.

18. Labauge P, Brunereau L, Laberge S, houteville J-P. Prospective followup of 33 asymptomatic patients with familial cerebral cavernous malformations. Neurology 2001;57:1825-1828.

19. Labauge P, Enjolras O, Bonerandi JJ et al. An association between autossomal dominante cerebral cavernomas and a distinctive hyperkeratotic vascular malformation in 4 families. Ann Neurol 1999;45:250-254.

20. Laberge-Le-Couteuls S, Brezin A, Fontaine B, Tournier-Lasserve E, Labauge P. KRIT-1/ CCM 1 trunkating mutation in a patient with cerebral and retinal cavernous angioma. Arch Ophthalmol 2002;120:217-218.

21. Denier C, Labauge P, bergametti F. Genotype-Phenotype correlations in cerebral cavernous malformations patients. Ann Neurol 2006;60:550-556.

22. Pozzati E, Zuchelli M, Riccioli LA. Bleeding of a familial cerebral cavernous malformation after prophylactic anticoagulation therapy: case report. Neurosurg Focus 2006;21:E15. 